\title{
POLITIK HUKUM PENGISIAN JABATAN PUBLIK MELALUI MEKANISME ELECTORAL SYSTEM OLEH MANTAN NARAPIDANA
}

\author{
Suparto ${ }^{1}$, Umi Muslikhah ${ }^{2}$ \\ 1,2Fakultas Hukum, Universitas Islam Riau, Pekanbaru, Indonesia \\ Jl. Kaharuddin Nasution No. 113, Perhentian Marpoyan Pekanbaru, Riau - 28284 \\ Email: suparto@law.uir.ac.id, muslikhah@law.uir.ac.id
}

\begin{abstract}
The filling of public positions through the electoral system by ex-convicts, especially corruption, raises the pros and cons of the community. This is because corruption belongs to the category of extraordinary crimes (extraordinary crime). KPU as the organizer of the Election issued KPU Regulation No. 20 of 2008 which forbade the nomination of ex-convicts as legislative candidates. However, this regulation is contrary to Article 240 paragraph (1) letter $g$ of the Election Law. This study examines the legal politics of filling public positions through the electoral system mechanism by ex-convicts referring to the decision of the Supreme Court No. 46 P / HUM / 2018 and Constitutional Court Decision No. 42 / PUU-XIII / 2015.
\end{abstract}

Keywords; Verdict, Ex Inmate, Electoral System

\begin{abstract}
Abstrak
Pengisian jabatan publik melalui electoral system oleh mantan narapidana khususnya tindak pidana korupsi menimbulkan gejolak di kalangan masyarakat. Hal ini karena korupsi termasuk kategori kejahatan luar biasa (extraordinary crime). KPU sebagai penyelenggara Pemilu mengeluarkan Peraturan KPU No. 20 Tahun 2008 yang melarang pencalonan mantan narapidana sebagai calon legislative. Namun, aturan tersebut bertentangan dengan Pasal 240 ayat (1) huruf g Undang-Undang Pemilu. Tulisan ini mengkaji politik hukum pengisian jabatan public melalui mekanisme electoral system oleh mantan narapidana merujuk pada Putusan Mahkamah Agung No. 46P/ HUM/2018 serta Putusan Mahkamah Konstitusi No. 42/PUU-XIII/2015.
\end{abstract}

Kata Kunci; Putusan, Eks Narapidana, electoral system 


\section{PENDAHULUAN}

Dalam negara yang menganut demokrasi, jalanya pemerintahan berlangsung atas pesetujuan dari rakyat. Pengisian jabatan publik melalui mekanisme electoral system seperti Presiden dan anggota DPR, DPD serta DPRD Provinsi/Kabupaten/Kota dilaksanakan dengan pemilihan langsung oleh rakyat dalam pemilihan umum. Sehingga legitimasi pemerintahan yang berjalan diperoleh melaui pemilihan langsung oleh rakyat di negara tersebut.

Pemilu yang merupakan ciri atau tanda demokrasi di suatu negara yang demokratis menurut Ali Murtopo adalah sarana yang tersedia bagi rakyat untuk menjalankan kedaulatannya dan merupakan lembaga demokrasi. ${ }^{1}$

Tujuan utama pemilu salah satunya adalah untuk memilih perwakilan di parlemen yang dapat merepresentasikan aspirasi rakyat. Rakyat Indonesia memberikan mandat kepada perwakilanya di parlemen dan pemerintahan. Perwakilan di parlemen memiliki andil yang besar bersama pemerintah dalam menentukan kebijakan yang sesuai dengan aspirasi masyarakat luas.

Mengenai landasan ataupun dasar pelaksanaannya, Pelaksanaan pemilu di Indonesia didasarkan pada landasan berikut :

1) Landasan Ideal, yaitu Pancasila, terutama sila kerakyatan yang dipimpin oleh hikmat kebijaksanaan dalam permusyawaratan/ perwakilan.

2) Landasan Konstitusional, yaitu UUD 1945 yang termuat di dalam :

i. Pembukaan Alinea ke empat

ii. Batang Tubuh pasal 1 ayat 2, Pasal 7, Pasal 19 ayat 1 dan 2, Pasal 22E.

iii. Penjelasan Umum tentang sistem pemerintahan negara".

Menurut Harris G. Warren, Pemilu adalah kesempatan bagi para warga negara untuk memilih pejabat-pejabat pemerintah dan memutuskan apakah yang mereka inginkan untuk dikerjakan oleh pemerintah. Dan dalam membuat keputusannya itu para warga negara menentukan apakah sebenarnya yang mereka inginkan untuk dimiliki. Sedangkan menurut A.Sudiharto, pemilu adalah sarana demokrasi yang penting dan merupakan perwujudan yang nyata untuk keikut sertaan rakyat dalam

\footnotetext{
1 Bintan R. Saragih, Lembaga Perwakilan dan Pemilihan Umum di Indonesia (Jakarta: Gaya Media Pratama, 1987), hlm. 167.
} 
kehidupan kenegaraan. ${ }^{2}$ Bahwa Pemilu dalam konteks hak Sipil dan Politik, adalah hak rakyat mengontrol pemerintah antara lain, hak menyatakan pendapat baik secara langsung melalui unjuk rasa atau melalui media masa untuk melakukan control dan koreksi terhadap kebijakan pemerintah. Menurut Abdul Hakim Garuda Nusantara, pemilihan umum dalam perspektif hak asasi manusia merupakan pelaksanaan hak dasar politik rakyat yaitu, hak untuk ikut serta menentukan arah dan masa depan kehidupan bersama dalam suatu masyarakat bernegara. ${ }^{3}$

Menurut Parulian Donold, ada dua manfaat yang sekaligus sebagi tujuan atau sasaran langsung yang hendak dicapai dengan pelaksanaan lembaga politik Pemilu, yaitu pembentukan atau pemupukan kekuasaan yang abash (otoritas) dan mencapai tingkat keterwakilan politik (political representativeness). ${ }^{4}$

Pemilihan umum merupakan instrumen demokrasi yang amat penting dan strategis bagi suatu bangsa. Pemilu bukan saja menunjukkan sejauh mana pemilih memiliki kedaulatan dalam menentukan wakil-wakilnya yang akan duduk di parlemen, tetapi juga dapat menentukan kehidupan politik lima tahunan berupa kebijakan atau regulasi yang dikeluarkan. Arti penting pemilu sebagai salah satu instrumen bagi pemilih tersebut ditentukan oleh sejauh mana penyelenggaraannya mengikuti prinsip-prinsip pemilu yang demokratis, berkualitas, dan memberikan jaminan keadilan kepada setiap warga negara serta asas Pemilu yaitu Langsung, Umum, Bebas, Rahasia, Jujur dan Adil (LUBER \& JURDIL).

Menurut "Pasal 240 ayat (1) huruf g Undang-Undang Nomor 7 Tahun 2017 tentang Pemilihan Umum menyatakan Bakal calon anggota DPR, DPRD provinsi, dan DPRD kabupaten/kota adalah Warga Negara Indonesia dan harus memenuhi persyaratan: tidak pernah dipidana penjara berdasarkan putusan pengadilan yang telah memperoleh kekuatan hukum tetap karena melakukan tindak pidana yang diancam dengan pidana penjara 5 (lima) tahun atau lebih, kecuali secara terbuka dan jujur mengemukakan kepada publik bahwa yang bersangkutan mantan terpidana.

Ketentuan pada Pasal tersebut memberikan akses kepada mantan narapidana (Eks Napi) yang telah menjalani masa hukuman lima tahun atau lebih boleh

\footnotetext{
2 Ramlan Surbakti, Memahami Ilmu Politik ( Jakarta: PT. Grafindo, 1992), hlm. 15.

3 Ibid..., hlm. 122-123

4 Parulian Donald, Menggugat Pemilu ( Jakarta: Pustaka Sinar Harapan ), hlm. 8.
} 
mencalonkan diri selama yang bersangkutan mengumumkan pernah berstatus sebagai narapidana kepada publik.

Pemberian akses kepada mantan narapidana untuk dapat turut serta dalam pemilu legislative menimbulkan kontroversi sosial di kalangan masyarakat luas dan penyelenggara pemilu. Hal ini dikarenakan status sosial seseorang yang pernah dijatuhi hukuman, stigma yang muncul di masyarakat adalah cenderung negative memandang mantan narapidana. Sehingga di anggap tidak layak untuk diberikan kepercayaan mengelola dan menjalankan tanggung jawab di pemerintahan. Tingkat kepercayaan publik dalam konteks demokrasi dan pemberantasan korupsi pada lembaga legislatif khususnya DPR semakin rendah. Survei antikorupsi yang diselenggarakan Indonesia Corruption Watch (ICW) bersama dengan Polling Center pada 2017 menunjukkan hanya 8\% responden yang menilai DPR berperan dalam pemberantasan korupsi. ${ }^{5}$

\section{METODE PENELITIAN}

Jenis penelitian hukum yang digunakan dalam hal ini adalah penelitian hukum normatif Dalam penelitian hukum normatif ini penulis melakukan penelitian terhadap sistematika hukum dan asas-asas hukum.

Dalam penelitian ini analisis yang dilakukan adalah analisis kualitatif. Selanjutnya penulis menarik suatu kesimpulan secara deduktif, yaitu menarik kesimpulan dari hal-hal yang bersifat umum kepada hal-hal yang bersifat khusus.

\section{PEMBAHASAN DAN ANALISIS}

Demokrasi merupakan credo (menurut KBBI) suci dalam penyelenggaraan pemerintahan negara modern. Isu demokrasi menjadi tolak ukur keberadaan sebuah negara dalam pergaulan dunia internasional. Hal itu didasarkan pada alasan bahwa sistem demokrasi dipercaya sebagai suatu sistem yang mencerminkan mekanisme

\footnotetext{
5 A Sugirman, "Menakar Tujuan Hukum Dibalik Keberpihakan Putusan MA No . 46 P / HUM / 2018 Terhadap Koruptor Prodi Hukum Tata Negara Fakultas Syari ' ah dan Hukum Islam Institut Agama Islam Negeri ( IAIN ) Bone Keywords : Justice ; Corruption ; Supreme Court ; PKPU Abst," no. 46 (2018).
} 
politik yang dianggap mampu menjamin adanya pemerintah yang tanggap terhadap preferensi dan keinginan warga negaranya. ${ }^{6}$

Dalam “Pasal 2 ayat (1) Undang-Undang Dasar 1945 (UUD 1945) menyatakan Kedaulatan berada di tangan Rakyat dan dijalankan sepenuhnya menurut UndangUndang Dasar 1945". Dalam hal ini, rakyat mempunyai otoritas tertinggi untuk menetapkan berlaku tidaknya suatu ketentuan hukum dan untuk menjalankan serta mengawasi pelaksanaan ketentuan hukum itu. Dalam konsep demokrasi, pemerintah negara merupakan "government or rule by the people". ${ }^{7}$

Konstitusi atau UUD 1945 juga mengatur jaminan terhadap hak-hak rakyat termasuk didalamnya partisipasi rakyat dalam pemerintahan dan pembatasan terhadap kekuasaan pemerintah agar kekuasaan yang dipegangnya tidak disalahgunakan. Pengaturan tersebut sering disebut sebagai pemisahan atau pembagian kekuasaan dan perumusan hak-hak asasi rakyat menghubungkan konsep negara hukum dan konsep demokrasi.

Menurut Miriam Budiardjo konsep demokrasi dalam pemerintahan adalah dimana kedudukan pemerintahan yang terbatas kekuasaanya dan tidak dibenarkan bertindak sewenang-wenang terhadap warga negaranya. ${ }^{8}$

Dalam sistem hukum rechstaat, konsep demokratis dikatakan sebagai "negara kepercayaan timbal balik (de staat van het wederzijds vertrouwen)", yaitu kepercayaan dari rakyat pendukungnya bahwa kekuasaan yang diberikan tidak akan disalahgunakan dan kepercayaan dari penguasa bahwa dalam batas kekuasaanya dia mengharapkan kepatuhan dari rakyat pendukungnya. ${ }^{9}$

Beriringan dengan amanat konstitusi adanya jaminan kebebasan warga negara ikut serta dalam pemerintahan ditegaskan ke dalam UUD 1945 yaitu "semua warga negara bersamaan kedudukannya di dalam hukum dan pemerintahan". Prinsip ini dinamakan equality before the law, yakni norma yang menjamin perlindungan hak asasi warga negara.

Menurut Henry B. Mayo "A democratic political system is one in which public policies are made on a majority basis, by representatives subject to effective popular

${ }^{6}$ Muladi, Hak Asasi Manusia Hakekat Konsep dan Implikasinya dalam Perspektif Hukum dan Masyarakat Cetakan Ketiga ( Bandung: Refika Aditama, 2009), hlm. 76.

${ }^{7}$ Miriam Budiardjo, Dasar-Dasar Ilmu Politik (Jakarta: Gramedia, 1989), hlm. 14.

8 Ibid.., hlm. 107-108.

9 Philipus M. Hadjon, Perlindungan Hukum Bagi Rakyat di Indonesia ( Surabaya: Bina Ilmu, 1987), hlm. 76. 
control at periodic elections which are conducted on the principle of political equality and under conditions of political freedom ( sistem politik yang demokratis ialah di mana kebijaksanaan umum di tetntukan atas dasar mayoritas oleh wakil-wakil yang diawasi secara efektif oleh rakyat dalam pemilihan-pemilihan berkala yang didasarkan atas prinsip kesamaan politik dan diselenggarakan dalam suasana terjaminya kebebasan politik)".10

Henry B. Mayo menyatakan bahwa demokrasi didasari oleh beberapa nilai, yakni: ${ }^{11}$

1. Menyelesaikan perselisihan dengan damai dan secara melembaga (institutionalized peaceful settlement of conflict);

2. Menjamin terselenggaranya perubahan secara damai dalam suatu masyarakat yang sedang berubah (peaceful change in a charging society);

3. Menyelenggarakan pergantian pimpinan secara teratur (orderly succession of rulers);

4. Membatasi pemakaian kekerasan sampai minimum (minimum of coercion);

5. Mengakui serta menganggap wajar adanya keanekaragaman (diversity) dalam masyarakat yang tercermin dalam keanekaragaman pendapat, kepentingan serta tingkah laku;

6. Menjamin tegaknya keadilan.

Indonesia adalah Negara yang menerapkan Demokrasi, dalam Negara Demokrasi pelaksanaan Pemilihan Umum (PEMILU) menjadi salah satu sarana perwujudan kedaulatan rakyat sebagaimana yang tertuang dalam konstitusi. Pemilu juga merupakan tolak ukur bahwa demokrasi yang diterapkan memiliki kecenderungan otoriter atau konstitusional.

Menurut Affan Gafar, dalam konteks Indonesia, banyak sekali orang mencampuradukkan antara electoral laws dengan electoral processes. Di dalam ilmu politik yang disebut dengan electoral laws menurut Douglas Rae, adalah "those which govern the processes by which electoral preferences are articulated as votes and by which these votes are translated into distribution of governmental authority (typically parliamentary seats) among the competing political parties". Artinya sistem pemilihan

${ }^{10}$ Henry B. Mayo, An Introduction to Democratic Theory (New York: Oxford University Press, 1960), hlm. 70.

11 Miriam Budiardjo, Dasar.., Op,Cit, hlm. 118-119. 
dan aturan yang menata bagaimana Pemilu dijalankan serta distribusi hasil pemilihan umum. Sementara electoral process adalah mekanisme yang dijalankan di dalam pemilihan umum, seperti mekanisme penentuan calon dan cara berkampanye. ${ }^{12}$

Menurut Ramlan Surbakti, kegiatan pemilihan umum berkedudukan sebagai:

1) Mekanisme untuk menyeleksi para pemimpin dan alternative kebijakan umum;

2) Mekanisme untuk memindahkan konflik kepentingan dari masyarakat ke lembaga-lembaga perwakilan melalui wakil rakyat yang terpilih, sehingga integrasi masyarakat tetap terjaga; 13

Sejalan dengan apa yang disampaikan Ramlan Surbakti, lembaga negara penyelenggara PEMILU yaitu Komisi Pemilihan Umum (KPU) mengeluarkan beberapa Peraturan yang merepresentasikan mekanisme seleksi para pemimpin atau perwakilan rakyat di parlemen. Salah satu Peraturan yang diterbitkan oleh "KPU adalah Peraturan KPU (PKPU) No. 20 Tahun 2018 tentang Pencalonan Anggota DPR, DPRD Provinsi dan DPRD Kabupaten/Kota".

PKPU No. 20 Tahun 2018 tentang Pencalonan Anggota DPR, DPRD Provinsi dan DPRD Kabupaten/Kota memuat ketentuan larangan yang tegas mengenai pencalonan mantan narapidana dalam Pemilu Legislatif. Ketentuan tersebut termuat dalam "Pasal 4 ayat (3) bahwa dalam seleksi bakal calon secara demokratis dan terbuka sebagaimana dimaksud pada ayat (2), tidak menyertakan mantan terpidana bandar narkoba, kejahatan seksual terhadap anak, dan korupsi”. Ketentuan ini menunjukkan peraturan (norma hukum) yang dibuat tidak mengabaikan norma kesusilaan yang hidup dalam masyarakat.

Draft PKPU tersebut mengalami sedikit perubahan sebelum diberlakukan, khususnya terkait substansi larangan mantan terpidana korupsi. Pengaturan mengenai larangan mantan terpidana korupsi yang tadinya diatur dalam "Pasal 7 ayat (1) huruf h, akhirnya direvisi menjadi Pasal 4 ayat (3) PKPU yang intinya antara lain bermakna bahwa larangan mantan narapidana korupsi mendaftarkan diri

12 Ni'matul Huda \& Imam Nasef, Penataan Demokrasi \& Pemilu di Indonesia Pasca Reformasi ( Jakarta: Kencana, 2017), hlm. 44

13 Ramlan Surbakti, Memahami..., Op. Cit. hlm. 21. 
merupakan bagian dari proses seleksi bakal calon anggota legislatif dalam mekanisme partai yang bersangkutan".

KPU sebagai penyelenggara pemilu menjadikan Undang-Undang Nomor 28 Tahun 1999 tentang Penyelenggaraan Negara yang Bersih dan Bebas dari Korupsi, Kolusi dan Nepotisme sebagai acuan untuk menyusun larangan bagi mantan narapidana korupsi mendaftar sebagai calon anggota legislatif. Undang-undang tersebut mengatur tentang penyelenggaraan negara yang bersih dan bebas dari korupsi, kolusi dan nepotisme ${ }^{14}$.

Dalam Undang-Undang Nomor 28 Tahun 1999 tentang Penyelenggaraan Negara yang Bersih dan Bebas dari Korupsi, Kolusi dan Nepotisme diatur sejumlah kewajiban bagi para penyelenggara Negara, salah satunya yaitu dalam "Pasal 5 Angka 4 yang berbunyi, Setiap penyelenggara negara berkewajiban untuk tidak melakukan perbuatan korupsi, kolusi dan nepotisme".

Undang-Undang Nomor 28 Tahun 1999 tentang Penyelenggaraan Negara yang Bersih dan Bebas dari Korupsi, Kolusi dan Nepotisme menjadi acuan PKPU No. 20 Tahun 2008 dengan asumsi bahwa kelak bakal calon Legislative/peserta Pemilu Legislatif berpeluang memperoleh jabatan publik. Perolehan jabatan publik tersebut memberikan peran kepada yang bersangkutan untuk turut aktif dalam penyelenggaraan negara serta pemerintahan. Dengan dikeluarkanya PKPU tersebut, merupakan langkah preventif agar pengisian jabatan publik dengan mekanisme electoral system melahirkan individu-individu yang kredible dan memiliki integritas yang tinggi serta mewujudkan penyelenggaraan Negara yang bersih dan bebas korupsi, kolusi dan nepotisme.

Namun, keberadaan PKPU tersebut bertentangan dengan ketentuan Pasal 240 ayat (1) hurf g Undang-Undang Nomor 7 Tahun 2017 tentang Pemilihan Umum yang memberikan akses kepada mantan narapidana yang telah menjalani masa hukuman lima tahun atau lebih boleh mencalonkan diri selama yang bersangkutan mengumumkan pernah berstatus sebagai narapidana kepada publik. Mahkamah Agung mengeluarkan putusan No. 46/HUM/2018 yang menyatakan ketentuan Pasal 4 ayat (3), Pasal 11 ayat (1) huruf d serta lampiran B.3 PKPU No. 20 Tahun 2018 
tentang Pencalonan Anggota Dewan Perwakilan Rakyat, Dewan Perwakilan Rakyat Daerah Provinsi, Dewan Perwakilan Rakyat Daerah Kabupaten/Kota sepanjang frasa "mantan terpidana korupsi" bertentangan dengan peraturan perundang-undangan yang lebih tinggi, yaitu dengan Undang-Undang Nomor 7 Tahun 2017 tentang Pemilihan Umum jo Undang-Undang Nomor 12 Tahun 2011 tentang Pembentukan Peraturan Perundang-undangan.

Selain itu jika di kaji dengan konstitusi, PKPU tersebut dianggap bertentangan dengan Pasal 28 huruf D UUD 1945 "Setiap orang berhak memperoleh kesempatan yang sama dalam pemerintahan". Pertentangan tersebut diuji di Mahkamah Konstitusi, Mahkamah Konstitusi telah mengeluarkan beberapa putusan terkait hal ini. Putusan Nomor 14-17/PUU-V/2007, Putusan Nomor 4/PUU-VII/2009, Putusan Nomor 120/PUU-VII/2009, Putusan Nomor 79/PUU-X/2012 dan terakhir Putusan Nomor 42/PUU-XIII/2015.

Pertentangan PKPU No. 20 Tahun 2008 dengan UU No. 7 tahun 2017 dikaji dari latar belakang arah pengaturan substansi Pasal 240 ayat (1) huruf g Undang-Undang No. 7 Tahun 2017 yang mendasarkan pada pertimbangan substansi norma yang terdapat dalam Putusan Mahkamah Konstitusi (MK) No 42 Tahun 2015. Putusan MK ini menegaskan bahwa Pasal 7 huruf g Undang-Undang Nomor 8 Tahun 2015 tentang Perubahan atas Undang-Undang Nomor 1 Tahun 2015 tentang Penetapan Peraturan Pemerintah Pengganti Undang-Undang Nomor 1 Tahun 2014 tentang Pemilihan Gubernur, Bupati, dan Walikota Menjadi Undang-Undang ialah bertentangan dengan UUD NRI Tahun 1945 secara bersyarat sepanjang tidak dimaknai “dikecualikan bagi mantan terpidana yang secara terbuka dan jujur mengemukakan kepada publik bahwa yang bersangkutan mantan terpidana".

Pendapat MK dalam putusanya, ketentuan Pasal 7 huruf g Undang Nomor 8 Tahun 2015 tentang Perubahan atas Undang-Undang Nomor 1 Tahun 2015 tentang Penetapan Peraturan Pemerintah Pengganti Undang-Undang Nomor 1 Tahun 2014 tentang Pemilihan Gubernur, Bupati, dan Walikota Menjadi Undang-Undang merupakan bentuk pengurangan hak atas kehormatan, yang dapat dipersamakan dengan pidana pencabutan hak-hak tertentu. Menurut MK pencabutan hak pilih seseorang hanya dapat dilakukan dengan putusan hakim sebagai hukuman tambahan. Undang-Undang tidak dapat mencabut hak pilih seseorang, melainkan 
hanya memberi pembatasan-pembatasan yang tidak bertentangan dengan UUD 1945, yang dalam Pasal 28 J ayat (2) UUD 1945 bahwa pembatasan dilakukan untuk menjamin pengakuan serta penghormatan atas hak dan kebebasan orang lain dan untuk memenuhi tuntutan yang adil dan sesuai dengan pertimbangan moral, nilai agama, keamanan dan ketertiban umum dalam masyarakat yang demokratis.

Dalam pertimbangannya pula hakim MK menyatakan bahwa seseorang yang telah menjalani hukuman dan keluar dari penjara pada dasarnya adalah orang yang telah menyesali perbuatannya, telah bertaubat, dan berjanji untuk tidak mengulangi lagi perbuatannya. Dengan demikian, seseorang mantan narapidana yang sudah bertaubat tersebut tidak tepat jika diberikan hukuman lagi oleh Undang-Undang seperti yang ditentukan dalam Pasal 7 huruf g UU No. 8 Tahun 2015.

Nilai dari suatu norma hukum hasil Putusan MK itulah yang menjadikan pembentuk UU Pemilu tidak membatasi terkait hak politik para mantan narapidana untuk mendaftar sebagai bakal calon legislatif, yakni "sepanjang tidak dimaknai dikecualikan bagi mantan terpidana yang secara terbuka dan jujur mengemukakan kepada publik bahwa yang bersangkutan mantan terpidana". Dengan demikian norma tersebut akan tetap sejalan dengan substansi norma dalam Putusan MK No 42 Tahun 2015 dan Putusan MK Nomor 4 Tahun 2009.15

Hakim konstitusi I Dewa Gede Palguna dan Suhartoyo menyampaikan dalam Disenting Opinion Putusan Mahkamah Konstitusi Nomor 42/PUU-XIII/2015, inti pendapat Mahkamah dalam putusan-putusannya tersebut adalah bahwa norma Undang-Undang yang materi muatannya seperti yang termuat dalam Pasal 7 huruf g UU 8 Tahun 2015 tentang Perubahan Atas Undang-Undang Nomor 1 Tahun 2015 Tentang Penetapan Peraturan Pemerintah Pengganti Undang-Undang Nomor 1 Tahun 2014 Tentang Pemilihan Gubernur, Bupati, Dan Walikota adalah inkonstitusional bersyarat (conditionally unconstitutional). Syaratnya ialah:

1. Berlaku bukan untuk jabatan-jabatan publik yang dipilih (elected officials) sepanjang tidak dijatuhi pidana tambahan berupa pencabutan hak pilih oleh putusan pengadilan yang telah mempunyai kekuatan hukum tetap;

15 Prianter Jaya Hairi, “Peraturan kpu no. 20 tahun 2018 dalam perspektif hierarki norma hukum 1,” no. 1 (2019): $1-6$. 
2. Berlaku terbatas untuk jangka waktu 5 (lima) tahun setelah mantan terpidana selesai menjalani pidana penjara berdasarkan putusan pengadilan yang telah mempunyai kekuatan hukum tetap;

3. Kejujuran atau keterbukaan mengenai latar belakang jati dirinya sebagai mantan terpidana;

4. Bukan sebagai pelaku kejahatan berulang-ulang. Keempat syarat tersebut bersifat kumulatif.

I Dewa Gede Palguna dan Suhartoyo menjelaskan lebih lanjut bahwa konstitusi harus dan mampu menjadi living constitution karenanya senantiasa timbul tuntutan, terutama bagi Mahkamah untuk menginterpretasiaknya sejalan dengan perkembangan masyarakat.

Hal yang menjadi pertimbangan dalam putusan ini menyangkut kekhususan karakter jabatan-jabatan publik tertentu menyebabkan tidak semua jabatan publik dapat ditentukan persyaratan dengan menggunakan rumusan norma yang bersifat umum sehingga perlu pembedaan persyaratan antara lain:

1. Jabatan publik yang dipilih (elected officials) dan jabatan publik yang diangkat (appointed officials);

2. Jabatan publik di bidang eksekutif yang lebih bersifat melayani dan jabatan publik di bidang legislatif yang bersifat menyalurkan aspirasi rakyat; dan

3. Jabatan publik yang karena tugasnya membutuhkan tingkat kepercayaan yang sangat tinggi, seperti hakim dan aparat penegak hukum lainnya, dan pejabat yang mengelola keuangan negara. ${ }^{16}$

Pertimbangan sosiologis dan historis Mahkamah Konstitusi dalam memutus perkara ini yakni kebijakan amnesti terhadap para anggota PRRI/Permesta dan GAM yang pada waktu itu juga telah melakukan tindak pidana yang cukup berat ancaman hukumannya menurut hukum positif Indonesia. Pihak yang terlibat dalam pemberontakan G.30.S/PKI yang persyaratan tidak terlibat secara langsung atau tidak langsung agar dapat menjadi calon anggota DPR, DPD, dan DPRD telah 
dinyatakan tidak konstitusional oleh Mahkamah melalui putusan Nomor 1117/PUU-I/2003 tanggal 24 Februari 2004. ${ }^{17}$

Hukum positif hingga kini tidak melarang mantan narapidana mencalonkan diri dalam pemilihan legislatif dan hanya pengadilanlah yang mempunyai kewenangan untuk mencabut hak politik seseorang. Namun memperluas tafsir undang-undang diperlukan karena korupsi adalah termasuk kedalam kejahatan yang luar biasa. ${ }^{18}$

Dalam perkembangan lembaga penyelenggara pemilu (KPU) mencoba membatasi khusus pada kejahatan korupsi tidak bisa turut serta kandidat dalam pemilihan umum. Korupsi merupakan faktor penghalang pembangunan ekonomi, sosial, politik dan budaya bangsa. Semangat Undang-Undang No. 31 Tahun 1999 tentang Pemberantasan Tindak Pidana Korupsi, Undang-Undang No. 20 Tahun 2001 tentang Perubahan atas Undang-Undang Nomor 31 Tahun 1999 tentang Pemberantasan Tindak Pidana Korupsi, dan Undang-Undang No. 30 Tahun 2002 tentang Komisi Pemberantasan Tindak Pidana Korupsi tidak terlepas dari semangat dunia internasional yang mencetuskan Declaration of 8 th International Conference Against Corruption tanggal 7-11 September 1977 di Lima yang mencetuskan pemberantasan korupsi secara internasional. Indonesia melakukan ratifikasi United Nations Convention Against Corruption (UNCAC) berdasarkan Resolusi 58/4 tanggal 31 Oktober 2003 sebagaimana ditentukan dalam Undang-Undang Nomor 7 Tahun 2006 tentang Pengesahan Konvensi Perserikatan Bangsa-Bangsa Anti Korupsi 2003. Korupsi merupakan penyalahgunaan jabatan publik untuk kepentingan pribadi ${ }^{19}$. Selain itu korupsi merupakan tindakan penyalahgunaan yang dilakukan pemerintah $^{20}$. Korupsi terdiri dari subjek korupsi, motivasi, maksud, cara dan konsekuensi dari perbuatan korupsi yang dilakukan. Korupsi dilakukan dengan menyalahgunakan kekuasaan dan melanggar kode etik yang ada ${ }^{21}$. Korupsi masuk ke dalam kategori kejahatan yang luar biasa. Korupsi merupakan musuh bersama dan musuh internasional. Korupsi menyebabkan kemiskinan di suatu Negara.

17 Ibid.

18 Hapsari, “Dilema Pelarangan Mantan Narapidana Korupsi Mendaftarkan Diri Sebagai Calon Legislatif."

19 Tanjung dan Saraswati, "Demokrasi Dan Legalitas Mantan Narapidana Dalam Pemilihan Kepala Daerah Dan Pemilihan Umum."

20 Na Tang, Zi Ding, dan Yanni Xu, "Corruption and Anti-Corruption Research in China: A Critical Review of Chinese Top Journal Publications (1989-2017)," Chinese Public Administration Review 9, no. 2 (Desember 20, 2018): 79.

${ }^{21}$ Zengke He, "Corruption and anti-corruption in reform China," Communist and Post-Communist Studies 33, no. 2 (Juni 2000): 243-270. 
Hasil survey Indonesian Corruption Watch tahun 2019 terhitung 40 orang dengan status mantan narapidana ikut serta dalam pencalonan legislative pada Pemilu Legislatif tahun 2019, Ke-40 caleg mantan napi koruptor itu tercatat dari 11 partai politik dan DPD RI. Mereka terdiri dari caleg anggota DPRD provinsi dan DPRD kabupaten/kota. Berikut ini nama-namanya:

Tabel I.1

Daftar Caleg DPRD Provinsi Mantan Narapidana Kasus Korupsi

\begin{tabular}{|c|c|c|c|}
\hline No & Partai Politik & Nama & Daerah Pemiihan \\
\hline \multirow{3}{*}{1} & \multirow{3}{*}{ Partai Gerindra } & Mohamad Taufik & DKI Jakarta \\
\hline & & Herry Jones Kere & Sulawesi Utara \\
\hline & & Husen Kausaha & Maluku Utara \\
\hline \multirow{3}{*}{2} & \multirow{3}{*}{ Partai Golkar } & Hamid Usman & Maluku Utara \\
\hline & & Desy Yusandi & Banten \\
\hline & & Agus Mulyadi R & Banten \\
\hline \multirow{3}{*}{3} & \multirow{3}{*}{ Partai Hanura } & Midasir & Jawa Tengah \\
\hline & & Welhelmus Tahalele & Maluku Utara \\
\hline & & Akhmad Ibrahim & Maluku Utara \\
\hline \multirow{2}{*}{4} & \multirow{2}{*}{ Partai Berkarya } & Meike Nangka & Sulawesi Utara \\
\hline & & Arief Armaiyn & Maluku Utara \\
\hline 5 & Partai Perindo & Samuel Buntuang & Gorontalo \\
\hline 6 & Partai Amanat Nasional & Abdul Fattah & Jambi \\
\hline 7 & Partai Bulan Bintang & Nasrullah Hamka & Jambi \\
\hline
\end{tabular}

Sumber : detik.com 
Tabel I.2

Daftar Caleg DPRD Kabupaten/Kota Mantan Narapidana Kasus Korupsi

\begin{tabular}{|c|c|c|c|}
\hline No & Partai Politik & Nama & Daerah Pemiihan \\
\hline \multirow{3}{*}{1} & \multirow{3}{*}{ Partai Gerindra } & Al Hajar Syahyan & Tanggamus \\
\hline & & Ferizal & Belitung Timur \\
\hline & & Mirhammuddin & Belitung Timur \\
\hline \multirow{4}{*}{2} & \multirow{4}{*}{ Partai Golkar } & Heri Baelanu & Pandeglang \\
\hline & & Dede Widarso & Pandeglang \\
\hline & & Saiful T Lami & Tojo Una-Una \\
\hline & & Edy Muklison & Blitar \\
\hline \multirow{2}{*}{3} & \multirow{2}{*}{ Partai Garuda } & Yulius Dakhi & Nias Selatan \\
\hline & & Ariston Moho & Nias Selatan \\
\hline 4 & Partai Berkarya & Yohanes Marianus Koa & Ende \\
\hline 5 & Partai Keadilan Sejahtera & Maksum DG Mannassa & Mamuju \\
\hline 6 & Partai Perindo & Zulfikri & Pagar Alam \\
\hline \multirow{3}{*}{7} & \multirow{3}{*}{ Partai Amanat Nasional } & Masri & Belitung Timur \\
\hline & & Muhammad Afrizal & Lingga \\
\hline & & Bahri Syamsu Arief & Cilegon \\
\hline \multirow{2}{*}{8} & \multirow{2}{*}{ Partai Hanura } & Warsit & Blora \\
\hline & & Moh Nur Hasan & Rembang \\
\hline \multirow{4}{*}{9} & \multirow{4}{*}{ Partai Demokrat } & Jones Khan & Pagar Alam \\
\hline & & Jhony Husban & Cilegon \\
\hline & & Syamsudin & Lombok Tengah \\
\hline & & Darmawaty Dareho & Manado \\
\hline \multirow{2}{*}{10} & \multirow{2}{*}{ PKP Indonesia } & Matius Tungka & Poso \\
\hline & & Joni Cornelius Tondok & Toraja Utara \\
\hline
\end{tabular}

Sumber: detik.com 
Tabel I.3

Daftar Caleg DPD Mantan Narapidana Kasus Korupsi

\begin{tabular}{|c|l|l|}
\hline No & \multicolumn{1}{|c|}{ Nama } & \multicolumn{1}{|c|}{ Daerah Pemiihan } \\
\hline 1 & Syahrul Kui Damapoli & Sulawesi Utara \\
\hline 2 & Abdullah Puteh & Aceh \\
\hline 3 & Abdillah & Aceh \\
\hline
\end{tabular}

Sumber: detik.com

Tabel I. 4

Tindak Pidana Korupsi Berdasarkan Profesi/Jabatan

\begin{tabular}{|l|c|c|c|c|c|c|}
\hline \multicolumn{1}{|c|}{ JABATAN } & $\mathbf{2 0 1 4}$ & $\mathbf{2 0 1 5}$ & $\mathbf{2 0 1 6}$ & $\mathbf{2 0 1 7}$ & $\mathbf{2 0 1 8}$ & JUMLAH \\
\hline Anggota DPR dan DPRD & 9 & 19 & 23 & 20 & 103 & 174 \\
\hline $\begin{array}{l}\text { Kepala } \\
\text { Lembaga/Kementerian }\end{array}$ & 9 & 3 & 2 & 0 & 1 & 15 \\
\hline Gubernur & 3 & 3 & 1 & 1 & 2 & 10 \\
\hline Walikota/Bupati dan Wakil & 12 & 4 & 9 & 13 & 30 & 68 \\
\hline Eselon I /II/III & 2 & 7 & 10 & 43 & 24 & 86 \\
\hline Hakim & 2 & 3 & 1 & 3 & 5 & 14 \\
\hline Jaksa & 0 & 0 & 3 & 1 & 0 & 4 \\
\hline Pengacara & 0 & 2 & 1 & 0 & 4 & 7 \\
\hline Swasta & 16 & 18 & 28 & 28 & 56 & 146 \\
\hline Lainya & 0 & 0 & 0 & 1 & 4 & 56 \\
\hline Korporasi & 3 & 21 & 13 & 31 & 5 \\
\hline
\end{tabular}

Sumber: Anti Corruption Clearing House - KPK

Dari tabel I. 4 di atas, pelaku tindak pidana Korupsi dengan profesi anggota DPR dan DPRD terbanyak dengan 174 kasus, pihak swasta sebanyak 147 kasus, Kepala Daerah tingkat II 68 kasus. Hal ini tentu memprihatinkan karena anggota legislatev 
merupakan lembaga perwakilan yang merepresentasikan dan menyalurkan aspirasi masyarakat di parlemen.

Sarana untuk memobilisasikan dukungan rakyat terhadap Negara dan pemerintahan dengan jalan ikut serta dalam proses politik. Mekanisme pelaksanaan Pemilu dengan rentang waktu lima tahun sekali merupakan sarana evaluasi kinerja pejabat publik oleh rakyat. Evaluasi kinerja ini memberikan gambaran bagi masyarakat mengenai keberlanjutan mereka sebagai pejabat publik (suksesi jabatan). Pejabat publik yang memiliki rekam prestasi tentu memiliki keunggulan tersendiri bagi pemilih, beda halnya dengan pejabat publik yang memiliki rekam jejak buruk, seperti pejabat publik yang pernah menjalani masa tahanan (eks narapidana). Masyarakat tentu dapat menilai mana yang layak atau tidak untuk mewakili mereka menyuarakan dan melaksanakan aspirasi mereka baik di perlemen ataupun di pemerintahan. Seperti kata pepatah "hanya keledai yang jatuh dua kali dalam lubang yang sama”.

\section{PENUTUP}

\subsection{Kesimpulan}

Pengisian jabatan publik secara election system oleh mantan narapidana diperkenankan pasca dikeluarkanya beberapa putusan Mahkamah Konstitusi, salah satunya Putusan Mahkamah Konstitusi Nomor 42/PUU-XIII/2015. Undang-Undang tidak berhak mencabut hak pilih warga negara Undang-Undang hanya memberikan batasan yang tidak bertentangan dengan UUD 1945, hak pilih seseorang hanya bisa dicabut melalui putusan hakim yang telah memiliki kekuatan hukum tetap. Pembatasan yang diberikan oleh Undang-Undang dalam hal ini berupa yang bersangkutan harus mengumumkan ke publik bahwa yang bersangkutan pernah dipidana serta buakn pelaku kejahatan berulang-ulang. Sehingga rakyat dapat berpikir kritis dan selektif dalam menentukan calon yang dipilihnya.

\subsection{Saran}

Pengisian jabatan public oleh mantan narapidana menimbulkan pro dan kontra di kalangan masyarakat luas, mengenai aspek jaminan Hak Asasi Manusia yang harus 
diberikan kepada seluruh Warga Negara Indonesia sebagai dasar pertimbangan keluarnya putusan Mahkamah Konstitusi mengenai ketentuan ini, ke depan diharapkan adanya regulasi yang tegas mengenai penanganan dan penjatuhan sanksi pada terdakwa yang terbukti melakukan tindak pidana penyalahgunaan kekuasaan (korupsi dan sebagainya) agar menimbulkan efek jera terhadap para pihak yang terkait.

\section{DAFTAR PUSTAKA}

\section{A. Buku}

Budiardjo, M. (1989). Dasar-Dasar Ilmu Politik. Jakarta: Gramedia.

Hadjon, P. M. (1987). Perlindungan Hukum Bagi Rakyat di Indonesia. Surabaya: Bina Ilmu.

Mayo, H. B. (1960). An Introduction to Democratic Theory. New York: Oxford University Press.

Muladi. (2009). Hak Asasi Manusia Hakekat Konsep dan Implikasinya dalam Perspektif Hukum dan Masyarakat Cet. Ketiga. Bandung: Refika Aditama.

Ni'matul Huda \& Imam Nasef. (2017). Penataan Demokrasi \& Pemilu di Indonesia Pasca Reformasi. Jakarta: Kencana.

Saragih, B. R. (1987). Lembaga Perwakilan dan Pemilihan Umum di Indonesia. Jakarta: Gaya Media Pratama.

Surbakti, R. (1992). Memahami Ilmu Politik. Jakarta: PT. Grasindo.

\section{B. Jurnal}

Hairi, Prianter Jaya. "Peraturan kpu no. 20 tahun 2018 dalam perspektif hierarki norma hukum 1," no. 1 (2019): 1-6.

Hapsari, Hanum. "Dilema Pelarangan Mantan Narapidana Korupsi Mendaftarkan Diri Sebagai Calon Legislatif." Jurnal UNNES (2018): 136-153.

$\mathrm{He}$, Zengke. "Corruption and anti-corruption in reform China." Communist and PostCommunist Studies 33, no. 2 (Juni 2000): 243-270.

Sugirman, A. "Menakar Tujuan Hukum Dibalik Keberpihakan Putusan MA No . 46 P / HUM / 2018 Terhadap Koruptor Prodi Hukum Tata Negara Fakultas Syari ' ah dan Hukum Islam Institut Agama Islam Negeri ( IAIN ) Bone Keywords : Justice ; Corruption ; Supreme Court; PKPU Abst," no. 46 (2018).

Tang, Na, Zi Ding, dan Yanni Xu. "Corruption and Anti-Corruption Research in China: A Critical Review of Chinese Top Journal Publications (1989-2017)." Chinese Public Administration Review 9, no. 2 (Desember 20, 2018): 79.

Tanjung, Muhammad Anwar, dan Retno Saraswati. “Demokrasi Dan Legalitas Mantan 
Narapidana Dalam Pemilihan Kepala Daerah Dan Pemilihan Umum." Jurnal Hukum Ius Quia Iustum 25, no. 2 (2018): 379-399.

\section{Peraturan Perundang-Undangan}

Undang-Undang Dasar 1945

Undang-Undang Nomor 28 Tahun 1999 tentang Penyelenggaraan Negara yang Bersih dan Bebas dari Korupsi, Kolusi dan Nepotisme.

UU 8 Tahun 2015 tentang Perubahan Atas Undang-Undang Nomor 1 Tahun 2015 Tentang Penetapan Peraturan Pemerintah Pengganti Undang-Undang Nomor 1 Tahun 2014 Tentang Pemilihan Gubernur, Bupati, Dan Walikota.

Undang-Undang Nomor 7 Tahun 2017 tentang Pemilihan Umum.

Peraturan KPU (PKPU) No. 20 Tahun 2018 tentang Pencalonan Anggota DPR, DPRD Provinsi dan DPRD Kabupaten/Kota. 